\title{
"PENGARUH PO (PENILAIAN OBJEKTIF) PEMBIMBING DAN PO (PENILAIAN OBJEKTIF) PENGUJI TERHADAP KUALITAS KELULUSAN MAHASISWA PADA PERGURUAN TINGGI RAHARJA".
}

Ageng Setiani Rafika ${ }^{1}$

Ki Ahmad Saputro ${ }^{2}$

Riyan Nova Saputra

E-mail:

agengsetianirafika@raharja.info,ahmad.saputro@raharja.info,riyan.rns@raharja.info

\begin{abstract}
ABSTRAKSI
Saat ini banyak lulusan mahasiswa yang tidak dapat diserap oleh dunia kerja atau pasar kerja karena memiliki kualitas yang buruk. Hal ini disebabkan oleh beberapa faktor yaitu mahasiswa sebagai peserta didik, dosen sebagai pengajar, dan kampus sebagai institusi penyambung antara dosen dan mahasiswa atau pemberi fasilitas kepada mahasiswa dan dosen. Tujuan penelitian ini untuk mengetahui pengaruh tingkat kedisiplinan mahasiswa dalam menjalankan bimbingan skripsi serta untuk mengetahui pengaruh PO Pembimbing dan PO Penguji terhadap tingkat kualitas kelulusan mahasiswa. Penelitian ini menggunakan pendekatan kuantitatif dengan metode survei deskriptif korelasional. Tehnik pengambilan Sampel dalam penelitian ini didasari atas perhitungan rumus Slovin sebanyak 61 orang. Alat pengumpul data menggunakan kuesioner dan dokumentasi. Analisis data menggunakan analisis statistik deskriptif dan analisis statistik iferensial. Pengolahan data menggunakan program SPSS. Hasil dari penelitian menunjukkan bahwa semakin baik tingkat penyelesaian Penilaian Objektif Pembimbing, akan semakin baik tingkat kualitas kelulusan mahasiswa karena nilai yang diterima akan semakin baik pula dan otomatis IPK pun naik. Tetapi, semakin baik tingkat penyelesaian Penilaian Objektif Penguji, tidak akan terlalu mempengaruhi tingkat kualitas kelulusan mahasiswa.
\end{abstract}

Kata Kunci : kedisiplinan mahasiswa, bimbingan skripsi, PO Pembimbing dan PO Penguji, kualitas kelulusan.

\section{ABSTRACT}

Currently, many graduate students who can't be absorbed by the world of work or labor market because of poor quality. It is caused by several factors such as students as learners, lecturer as a teacher, and the campus as a connector between the institution or any of its faculty and students to students and faculty facilities. The purpose of this study was to determine the effect of student discipline in implementing the guidance of the thesis as well as to determine the influence of $P O$ coach and PO testers on the level of quality of graduation.

This study uses a quantitative approach with descriptive correlational survey method. The sample collection technique is based on the calculation formula Slovin as many as 61 people. Data was collected using questionnaires and documentation. Analyzed using descriptive statistics and statistical analysis iferensial. Data processing using SPSS.

Results of the study showed that the better the level of completion of Objective Assessment Supervisor, the better the quality level graduation because the value received will better the automatic IPK and also rose. However, the better the level of completion of Objective Assessment Examiners, will not affect the level of quality of the graduation. 
Keywords : student discipline, guidance thesis , PO coach and PO testers, quality graduation .

\section{PENDAHULUAN}

Kualitas kelulusan di dalam suatu institusi pendidikan adalah suatu keberhasilan atau kegagalan suatu institusi pendidikan dalam menampilkan kinerjanya sebagai pengajar dan pemberi ilmu kepada peserta didik. Kualitas kelulusan mahasiswa adalah kualitas mutu seorang mahasiswa setelah mengikuti perkuliahan dari semester awal hingga semester akkhir kemudian menjalankan TA Skripsi / Skripsi apakah mampu bersaing dengan lulusan-lulusan universitas atau perguruan tinggi lainnya di dalam dunia nyata yaitu dunia kerja.

Saat ini banyak lulusan mahasiswa yang tidak dapat diserap oleh dunia kerja atau pasar kerja karena memiliki kualitas yang buruk. Hal ini disebabkan oleh beberapa faktor yaitu mahasiswa sebagai peserta didik, dosen sebaagai pengajar, dan kampus sebagai institusi penyambung antara dosen dan mahasiswa atau pemberi fasilitas kepada mahasiswa dan dosen.

Faktor dominan lebih banyak disebabkan oleh mahasiswa itu sendiri dan biasanya disebabkan oleh beberapa faktor nilai ( Indeks Mutu Kumulatif) yang identik dengan kualitas kelulusan mahasiswa. Pada saat perkuliahan, pertama kemalasan untuk mengikuti perkuliahan (bolos), hal ini dapat menyebabkan seorang mahasiswa tidak mendapatkan materi atau ilmu yang diberikan dosen serta absen yang kurang yang akan mempengaruhi nilai, kedua malas mengerjakan tugas dari dosen juga dapat mengurangi nilai di mata kuliah tersebut, kemudian saat menjalankan TA atau Skripsi jarang mengikuti bimbingan yang waktunya telah ditetapkan oleh dosen pembimbing dan tidak mengikuti tugas-tugas yang diberikan dosen pembimbing.

Untuk itu, di akhir perkuliahan mahasiswa saat menjalankan penyusunan TA/Skripsi serta sidang akhir, untuk mengurangi atau meniadakan permasalahanpermasalahan yang ada, seorang dosen pembimbing wajib memberikan tugas $\mathrm{PO}$ (Penilaian Obyektif) kepada mahasiswa yang dibimbingnya agar tidak ada lagi permasalahan seperti dosen pembimbing yang terlalu berat memberikan tugas kepada mahasiswa bimbingannya yang mengakibatkan mahasiswanya menjadi malas untuk bimbingan. PO (Penilaian Obyektif) Pembimbing disini adalah point - point tugas yang sudah menjadi dasar (ditentukan oleh pihak kampus Perguruan Tinggi Raharja) setiap mahasiswa bimbingan harus melaksanakan dan sudah memiliki masing masing nilai dari setiap point penugasan. Jadi ketika mahasiswa sedang menyelesaikan laporan, harus didasari dengan PO Pembimbing agar mendapatkan nilai yang sempurna.

\section{LANDASAN TEORI}

\section{Pengertian Penilaian}

Menurut Nana Sudjana (1995: 3) bahwa penilaian mempunyai ciri-ciri adanya objek atau program yang dinilai dan adanya kriteria sebagai dasar untuk membandingkan antara kenyataan atau apa adanya dengan kriteria atau apa harusnya.

Menurut (BSNP 2007: 9), penilaian merupakan serangkaian kegiatan untuk memperoleh, menganalisis, dan menafsirkan data tentang proses dan hasil belajar peserta didik yang dilakukan secara sistematis dan berkesinambungan, sehingga menjadi informasi yang bermakna dalam pengambilan keputusan.

\section{Fungsi dan Tujuan Penilaian}

Fungsi dari penilaian menurut Nana Sudjana, (1995: 4) adalah sebagai berikut:

(1) Alat untuk mengetahui tercapai tidaknya tujuan intruksional.

(2) Umpan balik bagi perbaikan proses belajar mengajar.

(3) Dasar dalam menyusun laporan kemajuan belajar siswa kepada para orang tua.

\section{Vol.1 No.1 - Agustus 2015}


Sedangkan tujuan dari penilaian menurut Nana Sudjana, (1995: 4) adalah sebagai berikut:

1) Mendeskripsikan kecakapan belajar siswa sehingga dapat diketahui kelebihan dan kekurangannya dalam berbagai bidang studi atau mata pelajaran yang ditempuhnya.

2) Mengetahui keberhasilan proses pendidikan dan pengajaran di sekolah, yakni seberapa jauh keefektifannya dalam mengubah tingkah laku para siswa ke arah tujuan pendidikan yang diharapkan.

3) Menentukan tindak lanjut hasil penilaian, yakni melakukan perbaikan dan penyempurnaan dalam hal program pendidikan dan pengajaran serta strategi pelaksanaanya.

4) Memberikan pertanggungjawaban (accountability) dari pihak sekolah kepada pihak-pihak yang berkepentingan.

\section{Teknik Penilaian}

Menurut BSNP (2007)

teknik penilaian tersebut yaitu:

\section{Tes tertulis}

Tes tertulis adalah suatu teknik penilaian yang menuntut jawaban secara tertulis, baik berupa pilihan atau isian.

\section{Observasi}

Observasi atau pengamatan adalah teknik penilaian yang dilakukan dengan menggunakan indera secara langsung.

\section{Tes praktik}

Tes praktik, juga biasa disebut tes kinerja, adalah teknik penilaian yang menuntut peserta didik mendemonstrasikan kemahirannya

\section{Penugasan}

Penugasan adalah suatu teknik penilaian yang menuntut peserta didik melakukan kegiatan tertentu di luar kegiatan pembelajaran di kelas. Penugasan dapat diberikan dalam bentuk individual atau kelompok. Penugasan ada yang berupa pekerjaan rumah atau berupa proyek

\section{Tes lisan}

Tes lisan dilaksanakan melalui komunikasi langsung tatap muka antara peserta didik dengan seorang atau beberapa penguji.

\section{Penilaian portofolio}

Penilaian portofolio adalah penilaian yang dilakukan dengan cara menilai portofolio peserta didik. Portofolio adalah kumpulan karya-karya peserta didik dalam bidang tertentu yang diorganisasikan untuk mengetahui minat, perkembangan, prestasi, dan/atau kreativitas peserta didik dalam kurun waktu tertentu. Setiap akhir periode pembelajaran hasil karya atau tugas belajar dikumpulkan dan dinilai bersama-sama antara guru dan peserta didik, sehingga penilaian portofolio dapat memberikan gambaran secara jelas tentang perkembangan/kemajuan belajar peserta didik. (Mimin Haryati, 2008: 59).

\section{Jurnal}

Jurnal merupakan catatan pendidik selama proses pembelajaran yang berisi informasi kekuatan dan kelemahan peserta didik yang berkait dengan kinerja ataupun sikap peserta didik yang dipaparkan secara deskriptif.

\section{Penilaian diri}

Penilaian diri merupakan teknik penilaian dengan cara meminta peserta didik untuk mengemukakan kelebihan dan kekurangan dirinya berkaitan dengan kompetensi yang menjadi tujuan pembelajaran.

Menurut Mimin Haryati (2008: 67), menilai diri dapat memberikan manfaat/dampak positif terhadap perkembangan kepribadian seorang peserta didik diantaranya:

1.1 menumbuhkan rasa percaya diri, karena peserta didik diminta untuk menilai dirinya sendiri,

1.2 peserta didik dapat mengetahui kekurangan dan kelebihan diri sendiri, metode ini merupakan ajang instropeksi diri, 
1.3 memberikan motivasi untuk membiasakan dan melatih peserta didik untuk berbuat jujur dalam menyikapi suatu hal.

\section{Penilaian antarteman}

Penilaian antarteman merupakan teknik penilaian dengan cara meminta peserta didik untuk mengemukakan kelebihan dan kekurangan temannya dalam berbagai hal.

\section{Prinsip Penilaian}

Prinsip penilaian menurut Nana Sudjana (1995: 9) yang dimaksudkan adalah sebagaiberikut:

(1) Dalam menilai hasil belajar hendaknya dirancang sedemikian rupa sehingga jelas abilitas (segi) yang harus dinilai, materi penilaian, alat penilaian, dan interpretasi hasil penilaian.

(2) Penilaian hasil belajar hendaknya menjadi bagian integral dari proses belajarmengajar.

(3) Agar diperoleh hasil belajar yang objektif dalam pengertian menggambarkan prestasi dan kemampuan siswa sebagaimana adanya, penilaian harus menggunakan berbagai alat penilaian dan sifatnya komprehensif. Dengan sifat komprehensif dimaksudkan segi atau abilitas yang dinilainya tidak hanya aspek kognitif, tetapi juga aspek afektif dan psikomotoris.

(4) Penilaian hasil belajar hendaknya diikuti dengan tindak lanjutnya.

Depdiknas (2004 : 7) menyatakan bahwa prinsip atau kriteria penilaian yaitu:

(a) Validitas

Menilai apa yang seharusnya dinilai dan alat penilaian yang digunakan sesuai dengan kompetensi yang akan dicapai dan isinya mencakup semua kompetensi yang terwakili secara proporsional.

(b) Reliabilitas

Penilaian yang reliable memungkinkan perbandingan yang reliable dan menjamin konsistensi. (c) Terfokus pada kompetensi

Penilaian harus terfokus pada pencapaian kompetensi (rangkaian kemampuan), bukan pada penguasaan materi (pengetahuan).

(d) Keseluruhan atau komprehensif

Penilaian harus menyeluruh dengan menggunakan beragam cara dan alat untuk menilai beragam kompetensi atau kemampuan peserta didik, sehingga tergambar profil kemampuan peserta didik.

\section{(e) Objektivitas}

Penilaian harus dilaksanakan secara obyektif, untuk itu penilaian harus adil, terencana, berkesinambungan, menggunakan bahasa yang dapat dipahami peserta didik dan menerapkan kriteria yang jelas dalam pembuatan keputusan atau pemberian angka.

(f) Mendidik

Penilaian dilakukan untuk memperbaiki proses pembelajaran bagi guru dan meningkatkan kualitas belajar bagi peserta didik.

\section{Pengertian Objektif}

Teori objektif merupakan teori sastra yang memandang karya sastra sebagai dunia otonom, sebuah dunia yang dapat melepaskan diri dari siapa pengarangnya, dan lingkungan sosial budayanya.

Kriteria utama dalam memberikan penilaian secara objektif itu, menurut Graham Hough dan Wellek Warren adalah pada adanya:

1. Relevansi nilai-nilai eksistensi manusia yang terpapar melalui jalan seni, imajinasi maupun rekaan yang keseluruhannya memiliki kasatuan yang utuh, selaras, serta padu dalam pencapaian tujuan tertentu atau memiliki integritas, harmony, dan unity.

2. Daya ungkap, keluasan, serta daya pukau yang disajikan lewat texture serta penataan unsur-unsur kebahasaan maupun struktur verbalnya atau pada adanya consonantia dan klantas.

\section{Vol.1 No.1 - Agustus 2015}




\section{Pengertian Penilaian Objektif}

Menurut (Suryana Endang, 2014:01), Memberikan penilaian terhadap seseorang (murid, mahasiswa) oleh pendidik (guru, dosen) harus senantiasa mengacu pada objektivitas, atau dengan kata lain penilaian harus objektif jauh dari sifat-sifat yang mengandung unsur subjektif.

\section{PO Pembimbing}

Menurut (Setiani, 2014:01), PO Pembimbing adalah penilaian yang hasilnya lebih pasti, bisa diyakini keabsahannya, tidak melibatkan perkiraan dan asumsi terhadap subyek

\section{PO Penguji}

Menurut (Setiani, 2014:01), Penilaian Seseorang bisa saja salah di dalam menilai sesuatu atau terlalu subyektif dalam menilai sesesuatu, sehingga adakalanya kesimpulan dan hasil yang negatif yang diberikan terhadap seseorang yang dinilai.

\section{Skripsi dan TA Skripsi Pengertian Tugas Akhir dan Skripsi}

Karya tulis Ilmiah adalah suatu karya untuk menghasilkan ilmu pengetahuan atau sesuatu yang dapat dipertanggung jawabkan secara ilmiah dan dikerjakan menurut aturan atau tata cara tertentu yang telah diakui secara luas oleh para ahli sebagai metode ilmiah (Soedjono, 1992).

Skripsi adalah suatu karya tulis ilmiah, berupa paparan tulisan hasil penelitian yang membahas suatu masalah dalam bidang ilmu tertentu dengan menggunakan kaidah-kaidah yang berlaku dalam bidang ilmu tersebut (wikipedia, 2014:01).

\section{Pengertian Kualitas Lulusan}

Menurut Suyadi (2004:5), berkaitan dengan mutu lulusan (output), dapat dijelaskan bahwa output sekolah dikatakan bermutu tinggi, jika prestasi pendidik khususnya prestasi belajar peserta anak didik, menunjukkan pencapaian yang tinggi dalam hasil kemampuan akademik.

Akka (2013:01) menyatakan pendidikan yang bermutu adalah pendidikan yang mampu menghasilkan lulusan yang memiliki kemampuan atau kompotensi, baik kompetensi akademik maupun kompetensi kejuruan, yang dilandasi oleh kompetensi personal dan sosial, serta nilai-nilai akhlak mulia, yang keseluruhannya merupakan kecakapan hidup (life skill), lebih lanjut Sudradjat megemukakan pendidikan bermutu adalah pendidikan yang mampu menghasilkan manusia seutuhnya (manusia paripurna) atau manusia dengan pribadi yang integral (integrated personality) yaitu mereka yang mampu mengintegralkan iman, ilmu, dan amal.

\section{Karakteristik Kualitas Lulusan}

Usman (2006:411) mengemukakan 13 (tiga) belas karakteristik yang dimiliki oleh mutu pendidikan yaitu:

1. Kinerja (performa) yakni berkaitan dengan aspek fungsional sekolah meliputi: kinerja guru dalam mengajar baik dalam memberikan penjelasan meyakinkan, sehat dan rajin mengajar, dan menyiapkan bahan pelajaran lengkap, pelayanan administratif dan edukatif sekolah baik dengan kinerja yang baik setelah menjadi sekolah favorite.

2. Waktu wajar (timelines) yakni sesuai dengan waktu yang wajar meliputi memulai dan mengakhiri pelajaran tepat waktu, waktu ulangan tepat.

3. Handal (reliability) yakni usia pelayanan bertahan lama. Meliputi pelayanan prima yang diberikan sekolah bertahan lama dari tahun ke tahun, mutu sekolah tetap bertahan dan cenderung meningkat dari tahun ke tahun,

4. Daya tahan (durability) yakni tahan banting, misalnya meskipun krisis moneter, sekolah masih tetap bertahan,

5. Indah (aesteties) misalnya eksterior dan interior sekolah ditata menarik, guru membuat media-media pendidikan yang menarik,

\section{Vol.1 No.1 - Agustus 2015}


6. Hubungan manusiawi (personal interface) yakni menjunjung tinggi nilainilai moral dan profesionalisme. Misalnya warga sekolah saling menghormati, demokrasi, dan menghargai profesionalisme,

7. Mudah penggunaannya (easy of use) yakni sarana dan prasarana dipakai. Misalnya aturan-aturan sekolah mudah diterapkan, buku-buku perpustakaan mudah dipinjam di kembalikan tepat waktu,

8. Bentuk khusus (feature) yakni keuggulan tertentu misalnya sekolah unggul dalam hal penguasaan teknologi informasi (komputerisasi),

9. Standar tertentu (comformence to specification) yakni memenuhi standar tertentu. Misalnya sekolah telah memenuhi standar pelayanan minimal,

10. Konsistensi (concistency) yakni keajengan, konstan dan stabil, misalnya mutu sekolah tidak menurun dari dulu hingga sekarang, warga sekolah konsisten dengan perkataannya,

11. Seragam (uniformity) yakni tanpa variasi, tidak tercampur. Misalnya sekolah melaksanakan aturan, tidak pandang bulu, seragam dalam berpakaian,

12. Mampu melayani (serviceability) yakni mampu memberikan pelayanan prima. Misalnya sekolah menyediakan kotak saran dan saran-saran yang masuk mampu dipenuhi dengan baik sehingga pelanggan merasa puas,

13. Ketepatan (acuracy) yakni ketepatan dalam pelayanan misalnya sekolah mampu memberikan pelayanan sesuai dengan yang diinginkan pelanggan sekolah.

\section{PERMASALAHAN}

Di akhir perkuliahan mahasiswa saat menjalakan penyusunan TA/Skripsi serta sidang akhir, untuk mengurangi atau meniadakan permasalahan-permasalahan yang ada, seorang dosen pembimbing wajib memberikan tugas PO (Penilaian Obyektif) kepada mahasiswa yang dibimbingnya agar tidak ada lagi permasalahan seperti dosen pembimbing yang terlalu berat memberikan tugas kepada mahasiswa bimbingannya yang mengakibatkan mahassiwanya menjadi malas untuk bimbingan. PO (Penilaian Obyektif) Pembimbing disini adalah point - point tugas yang sudah menjadi dasar (ditentukan oleh pihak kampus Perguruan Tinggi Raharja) setiap mahasiswa bimbingan harus melaksanakan dan sudah memiliki masing masing nilai dari setiap point penugasan.

Setelah masalah diteliti itu ditentukan variabel yang akan diteliti, dan supaya masalah dapat terjawab secara akurat, maka masalah yang akan diteliti itu perlu dirumuskan secara spesifik, maka rumusan masalah itu dinyatakan dalam kalimat pertanyaan. Adapun perumusan masalahnya adalah sebagai berikut:

1. Apakah PO Pembimbing berpengaruh terhadap Kualitas kelulusan mahasiswa pada Perguruan Tinggi Raharja.

2. Apakah PO Penguji berpengaruh terhadap Kualitas kelulusan mahasiswa pada Perguruan Tinggi Raharja.

3. Apakah PO Pembimbing dan PO Penguji berpengaruh terhadap Kualitas kelulusan mahasiswa pada Perguruan Tinggi Rahaja.

\section{LITERATURE REVIEW}

Beberapa Literature review dalam penelitian ini sebagai berikut:

1. Penelitian ini dilakukan oleh Sofia Afritasari dari Universitas Sebelas Maret, pada tahun 2013 yang berjudul "Pengaruh Kompetensi Dosen Dan Motivasi Belajar Terhadap Prestasi Belajar Mahasiswa". Penelitian ini membahas tentang untuk mengetahui pengaruh kompetensi dosen dan motivasi belajar terhadap prestasi belajar mahasiswa.

2. Penelitian ini dilakukan oleh Rini Maryuni Hariyati dari STIE Malangkucecwara, pada tahun 2013 yang berjudul "Survey Kinerja Dosen Pembimbing Skripsi Dan Kualitas Skripsi Mahasiswa Akuntansi STIE Malangkucecwara". Penelitian ini membahas tentang untuk mengetahui kinerja dosen pembimbing skripsi dan kualitas 
skripsi mahasiswa STIE

Malangkucecwara.

3. Penelitian ini dilakukan oleh Drs. Dudung Amir Soleh M.Pd dari Universitas Negeri Jakarta, pada tahun 2009 yang berjudul "Kualitas Skripsi Mahasiswa PGSD FIP UNJ Sebagai Syarat Kelulusan Sarjana Pendidikan". Penelitian ini membahas tentang untuk mengidentifikasi jenis-jenis skripsi dan kualitas dari skripsi yang dibuat oleh mahasiswa PGSD FIP Universitas Negeri Jakarta.

4. Penelitian ini dilakukan oleh Basir Paly dari UIN Alauddin Makasar, pada tahun 2013 yang berjudul "Tingkat Kepuasan Mahasiswa Terhadap Kinerja Proses Belajar Mengajar (PBM) Dosen". Penelitian ini membahas tentang untuk mengetahui bagaimana tingkat kepuasan mahasiswa terhadap kinerja PBM dosen. Dengan pengetahuan tersebut, diharapkan adanya penyesuaian dan perbaikan mutu pelayanan.

5. Penelitian ini dilakukan oleh Bagus Andi Irawan dari UPN Veteran Jawa Timur, pada tahun 2013 yang berjudul "Pengaruh Kompetensi Dosen, Proses Pembelajaran, Dan Variasi Mengajar Dosen Terhadap Prestasi Mahasiswa Akuntansi UPN Veteran Jawa Timur". Penelitian ini membahas tentang untuk membuktikan dan menguji secara empiris pengaruh kompetensi dosen (X1), proses pembelajaran (X2), dan variasi mengajar dosen (X3) terhadap prestasi mahasiswa $(\mathrm{Y})$.

\section{PEMECAHAN MASALAH}

Dari uji hipotesis diperoleh hasil yang menunjukkan adanya hubungan antara PO Pembimbing dan Kualitas kelulusan mahasiswa, PO Penguji dan Kualitas kelulusan mahasiswa, serta PO Pembimbing dan PO Penguji secara bersama-sama dan kualitas kelulusan mahasiswa. Hasil tersebut juga menunjukkan:
1. Terdapat pengaruh positif dan signifikan antara PO Pembimbing terhadap Kualitas kelulusan mahasiswa pada Perguruan Tinggi Raharja dengan nilai sig. Sebesar 0,007 atau kurang dari 0,025. Terdapat korelasi yang bersifat cukup antara PO Pembimbing terhadap Kualitas kelulusan mahasiswa pada Perguruan Tinggi Raharja karena nilainya berada di kisaran $0,25-0,5$ yaitu 0,339 ;

Tabel 1. Rekapitulasi Hasil Perhitungan SPSS PO Pembimbing dan Kualitas kelulusan mahasiswa

\begin{tabular}{|l|r|}
\hline \multicolumn{1}{|c|}{ Keterangan } & \multicolumn{1}{|c|}{ Nilai } \\
\hline Koefisien Korelasi & 0,210 \\
Sig. (uji dua sisi) & 0,105 \\
Koefisien Determinasi & 0,044 \\
Regresi : & \\
Konstanta & 31,155 \\
PO Penguji & 0,309 \\
t Regresi & 1,648 \\
Sig. Regresi & 0,105 \\
\hline
\end{tabular}

2. Terdapat pengaruh positif tetapi tidak signifikan antara PO Penguji terhadap Kualitas kelulusan mahasiswa pada Perguruan Tinggi Raharja karena nilai sig. sebesar 0,105 atau lebih dari batas probabilitas uji dua sisi 0,025 . Terdapat korelasi yang bersifat sangat lemah antara PO Penguji terhadap Kualitas kelulusan mahasiswa pada Perguruan Tinggi Raharja karena nilainya berada di kisaran 0 - 0,25 yaitu 0,210 ;

3.

Tabel 2. Rekapitulasi Hasil Perhitungan SPSS PO penguji dan kualitas kelulusan mahasiswa

\begin{tabular}{|l|r|}
\hline Keterangan & \multicolumn{1}{|c|}{ Nilai } \\
\hline fisien Korelasi & 0,339 \\
Sig. (uji dua sisi) & 0,007 \\
Koefisien Determinasi & 0,115 \\
Regresi : & \\
Konstanta & 24,582 \\
PO Pembimbing & 0,314 \\
t Regresi & 2,772 \\
Sig. Regresi & 0,007 \\
\hline
\end{tabular}


Tabel 3. Korelasi Hasil Perhitungan SPSS PO penguji dan PO Penguji

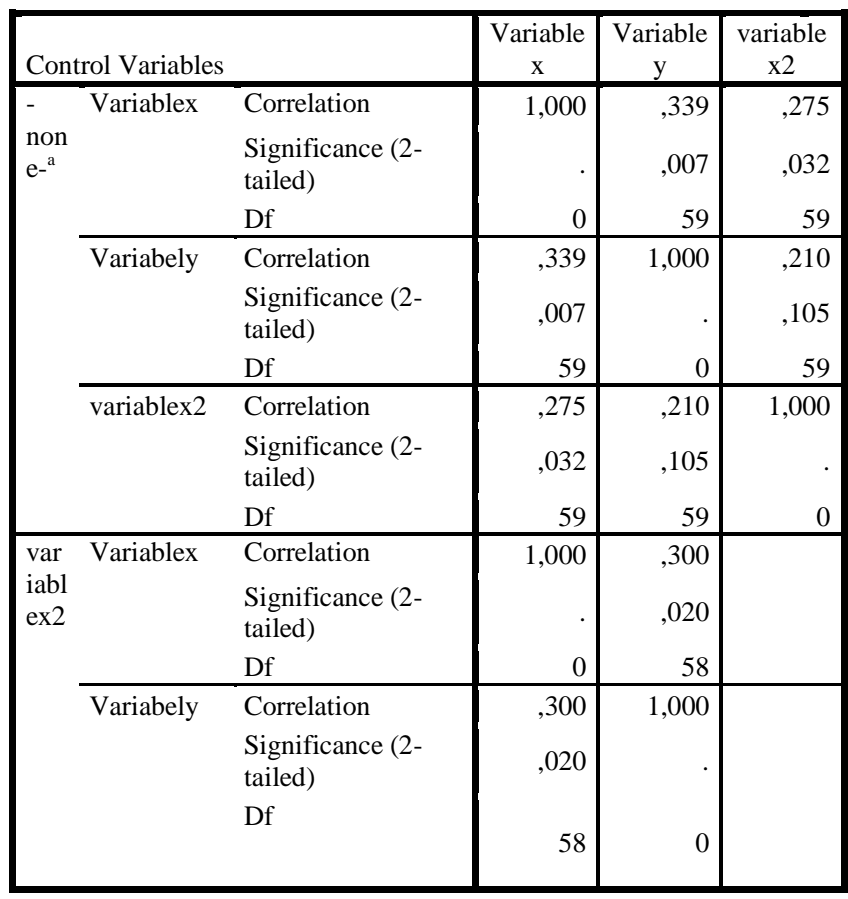

a. Cells contain zero-order (Pearson) correlations.

4. Terdapat pengaruh positif tetapi tidak signifikan antara PO Pembimbing dan PO Penguji karena nilai sig. sebesar 0,032 atau lebih dari batas probabilitas uji dua sisi 0,025 . Terdapat korelasi yang bersifat cukup antara PO Pembimbing dan PO Penguji karena nilainya berada di kisaran $0,25-0,5$ yaitu 0,275 ;

5. Terdapat pengaruh positif antara $\mathrm{PO}$ Pembimbing dan PO Penguji secara bersama-sama terhadap Kualitas kelulusan mahasiswa pada Perguruan Tinggi Raharja. Nilai sig. PO Pembimbing dan PO Penguji secara bersama-sama sebesar 0,020 dan 0,327 atau dapat dilihat hanya PO Pembimbing yang bersifat signifikan karena kurang dari batas probabilitas uji dua sisi 0,025 . Terdapat korelasi yang bersifat cukup antara PO Pembimbing dan PO Penguji secara bersama-sama terhadap Kualitas kelulusan mahasiswa pada Perguruan Tinggi Raharja karena nilainya berada di kisaran $0,25-0,5$ yaitu 0,360 , nilai korelasi ini lebih tinggi dari koefisien korelasi sederhana sebelumnya;

Tabel 4. Rekapitulasi Hasil Perhitungan SPSS PO penguji dan PO Penguji

\begin{tabular}{|l|r|}
\hline \multicolumn{1}{|c|}{ Keterangan } & \multicolumn{1}{|c|}{ Nilai } \\
\hline Koefisien Korelasi & 0,360 \\
Ganda & \\
Koefisien Determinasi & 0,130 \\
Nilai Uji F & 4,330 \\
Sig. F & 0,018 \\
Regresi : & \\
Konstanta & 19,209 \\
PO Pembimbing & 0,282 \\
Sig. & 0,020 \\
PO Penguji & 0,186 \\
Sig. & 0,327 \\
\hline
\end{tabular}

Dengan demikian dapat dinyatakan, semakin baik tingkat penyelesaian Penilaian Objektif Pembimbing, akan semakin baik tingkat kualitas kelulusan mahasiswa karena nilai yang diterima akan semakin baik pula dan otomatis IPK pun naik. Tetapi, semakin baik tingkat penyelesaian Penilaian Objektif Penguji, tidak akan terlalu mempengaruhi tingkat kualitas kelulusan mahasiswa.

\section{KESIMPULAN}

Berdasarkan uji hipotesis sebelumnya mengenai peranan PO Pembimbing dan PO Penguji pada Perguruan Tinggi Raharja, maka penulis dapat menyimpulkan bahwa terbentuknya sebuah sistem penilaian dengan PO pada Perguruan Tinggi Raharja, secara tidak langsung telah menjawab kendala yang dihadapi selama ini dan juga dapat meminimalisir kekurangan-kekurangan sebelumnya agar TA/Skripsi berjalan efisien serta efektif. Berdasarkan hasil penelitian dan uji hipotesis, maka Peneliti menyimpulkan sebagai berikut:

1. Terdapat pengaruh positif PO Pembimbing terhadap kualitas kelulusan mahasiswa. Pengaruh yang

\section{Vol.1 No.1 - Agustus 2015}


ditunjukkan bersifat signifikan. Semakin tinggi motivasi seorang mahasiswa menyelesaikan PO Pembimbing, akan semakin baik kualitas kelulusan mahasiswa tersebut. Sebaliknya, semakin rendah tingkat motivasi seorang mahasiswa menyelesaikan PO Pembimbing, akan semakin rendah pula kualitas kelulusan mahasiswa tersebut.

2. Terdapat pengaruh positif antara PO Penguji terhadap kualitas kelulusan mahasiswa. Tetapi, pengaruh ini tidak bersifat signifikan. Jadi, Semakin tinggi motivasi seorang mahasiswa menyelesaikan PO Penguji, tidak akan terlalu mempengaruhi kualitas kelulusan mahasiswa tersebut. Dan sebaliknya, juga seperti itu. Karena korelasi antara PO Penguji dan kualitas kelulusan mahasiswa lemah.

3. Terdapat pengaruh positif PO Pembimbing dan PO Penguji secara bersama-sama terhadap kualitas kelulusan mahasiswa. Tetapi, hasil statistik juga menunjukkan bahwa tidak terdapat pengaruh yang signifikan.

Dengan demikian dapat dinyatakan, semakin baik tingkat penyelesaian Penilaian Objektif Pembimbing, akan semakin baik tingkat kualitas kelulusan mahasiswa karena nilai yang diterima akan semakin baik pula dan otomatis IPK pun naik. Tetapi, semakin baik tingkat penyelesaian Penilaian Objektif Penguji, tidak akan terlalu mempengaruhi tingkat kualitas kelulusan mahasiswa.

\section{DAFTAR PUSTAKA}

1. Aminuddin. 1987. Pengantar Apresiasi Karya Sastra. Bandung: Sinar Baru Algesindo

2. BSNP.2007. Panduan Penilaian Kelompok Mata Pelajaran Ilmu Pengetahuan Dan Teknologi.

3. http://dikmenum.go.id/dataapp/kurikulum/3. \%20PANDUAN\%20PENILAIAN\%20KEL

\section{Vol.1 No.1 - Agustus 2015}

\%205\%20MAPEL/C_Panduan_Kel_Mapel_I pteks.pdf (diak ses tanggal 18Maret 2013).

4. Depdiknas. 2004. Kurikulum 2004 Pedoman Penilaian Kelas. Jakarta: Departemen Pendidikan Nasional.

5. Fananie, Sastra. Surakarta: Zainuddin. Telaah Muhammadiyah University Press.

6. Haryati, Mimin. 2008. Model dan Teknik Penilaian pada Tingkat Satuan Pendidikan. Jakarta: Gaung persada Press.

7. Ine Kusuma Aryanti, dan Markum Susatim.2010. Pendidikan Kewarganegaraan Berbasis Nilai.

8. Oemar, Hamalik.2002. Psikologi Belajar Mengajar. Bandung: Sinar Baru Algesindo.

9. Paul.D. Leedy and Jeanne.E. Ormrod. 2005. Practical Research: Planning and Design Research Edisi 8. Ohio: Pearson Merrill Prentice Hall. Page 156-209

10. Prawirosentono, Suyadi. 2004. Filosofi Baru Tentang Manajemen Mutu Terpadu Total Quality Management Abad 21 Studi Kasus dan Analisis. Jakarta: PT Bumi Aksara.

11. Rafika, Setiani. 2014. PO Pembimbing dan $P O$ Penguji. ageng.ilearning.me/? $\mathrm{p}=101$ (diakses pada 01 Juni 2014)

12. Santosa, Puji. Pengetahuan dan Apresiasi Kesusastraan. Jakarta: Nusa Indah.

13. Sakriah, Akka.2013. Kuliatas kelulusan. sakriahakka.blogspot.com/2013/10/kualitaslulusan.html ( diakses pada 6 Maret 2014)

14. Sudaryanti, Enny.2007. Pemahaman Guru IPS Terhadap Penilaian Kelas Berdasarkan Kurikulum Tingkat Satuan Pendidikan (KTSP) di SMP Negeri Kecamatan Jepara. Skripsi: Universitas Negeri Semarang.

15. Sudjana, Nana.1995. Penilaian Hasil Proses Belajar Mengajar. Bandung: PT Remaja Rosdakarya.

16. Wikipedia Indonesia. 2014. Skripsi. id.wikipedia.org/wiki/Skripsi\#cite_ref-1. diakses pada 6 Maret 2014 